\title{
Clinical and genetic heterogeneity of hypochondroplasia
}

Francis Rousseau, Jacky Bonaventure, Laurence Legeai-Mallet, Heinrich Schmidt, Jean Weissenbach, Pierre Maroteaux, Arnold Munnich, Martine Le Merrer

\begin{abstract}
Hypochondroplasia (HCH) is an autosomal dominant condition characterised by short stature, micromelia, and lumbar lordosis. In a series of $29 \mathrm{HCH}$ probands (13 sporadic cases, 16 familial cases), we tested their DNA for the N540K recurrent mutation previously described in the proximal tyrosine kinase domain of the FGFR3 gene on chromosome 4p16.3, and we detected this mutation in $21 / 29 \mathrm{HCH}$ patients. Interestingly, three familial cases were clearly unlinked to chromosome 4p16.3. Reviewing the clinical and radiological manifestations of the disease a posteriori, we observed that the N540K mutation was associated with relative macrocrania with a high and large forehead and short hands. By contrast, in the three pedigrees inconsistent with linkage to chromosome 4p16.3, the clinical phenotype was milder, macrocephaly and shortening of the long bones was less obvious, the hands were normal, and no metaphyseal flaring was noted. This study supports the view that $\mathrm{HCH}$ is a clinically and genetically heterogeneous condition. (F Med Genet 1996;33:749-752)
\end{abstract}

Key words: hypochondroplasia; heterogeneity.

Service de Génétique et Unité de Recherches sur les Handicaps Génétiques de l'Enfant, INSERM U393, CNRS ER 88, Institut Necker,

Hôpital des

Enfants-Malades, 149

rue de Sèvres, 75743

Paris Cedex 15, France

F Rousseau

J Bonaventure

L Legeai-Mallet

P Maroteaux

A Munnich

M Le Merrer

University Children's

Hospital, 80337

Munchen, Germany

H Schmidt

Généthon, 1 rue de l'Internationale, BP 60, 91002 Evry, France $\mathrm{J}$ Weissenbach

Correspondence to: Dr Le Merrer.

Received 4 December 1995 Revised version accepted fo publication 3 June 1996
Hypochondroplasia (HCH, MIM 146000) is an autosomal dominant condition characterised by short stature, micromelia, and lumbar lordosis. ${ }^{1}$ Clinical symptoms, radiological features, and histopathological aspects of the growth plate cartilage are similar to but milder than those seen in achondroplasia $(\mathrm{ACH}){ }^{2-4}$ $\mathrm{ACH}$ and $\mathrm{HCH}$ have long been regarded as allelic disorders based on (1) inter- and intrafamilial clinical variability of $\mathrm{HCH}$ with some cases resembling $\mathrm{ACH}$, and (2) the observation of severe dwarfism similar to homozygous $\mathrm{ACH}$ in the offspring of an $\mathrm{ACH}$ father and an $\mathrm{HCH}$ mother. ${ }^{5}$

In the last two years, the $\mathrm{ACH}$ gene has been mapped to chromosome $4 \mathrm{p} 16.3^{67}$ and a common mutation (G380R) in the transmembrane domain of the fibroblast growth factor receptor 3 (FGFR3) gene has been identified in more than $98 \%$ of $\mathrm{ACH}$ patients. ${ }^{8-10}$ On the other hand, family studies supported allelism of $\mathrm{ACH}$ and $\mathrm{HCH}^{711}$ and a recurrent mutation in the proximal tyrosine kinase (TK1) domain of the FGFR3 gene has been identified in $\mathrm{HCH}$ $(\mathrm{N} 540 \mathrm{~K}) .{ }^{12}$ Yet other $\mathrm{HCH}$ cases were clearly unlinked to chromosome $4 \mathrm{p} 16.3 .^{14}{ }^{15}$
Studying a series of 29 patients, we report here on the clinical and genetic heterogeneity of $\mathrm{HCH}$ and show that the clinical severity of $\mathrm{HCH}$ ascribed to FGFR3 mutations is greater than that of $\mathrm{HCH}$ unlinked to chromosome 4 p16.3.

\section{Patients and methods}

Twenty nine $\mathrm{HCH}$ probands (13 sporadic cases and 16 familial cases) with at least two affected subjects over at least two generations were included in the study. Minimal criteria for inclusion were a disproportional short limb dwarfism (height below -2 SD) and $x$ ray evidence of shortening of the long bones with reduced interpedicular distances or an absence of normal increase in lumbar spinal column (front view) and short pedicles (lateral view)..$^{2-4}$

For linkage analyses in familial $\mathrm{HCH}$, an EDTA blood sample $(20 \mathrm{ml})$ was collected from each family member and DNA was prepared from lymphocyte pellets by SDS lysis, proteinase $\mathrm{K}$ digestion, phenol chloroform extraction, ethanol precipitation, and Tris-EDTA resuspension. For genotyping with the hypervariable microsatellite DNA markers of chromosome 4, genomic DNA (50 ng) was amplified using $1 \mathrm{U}$ Taq polymerase in a buffer containing $50 \mathrm{pmol}$ of each primer, $6.25 \mathrm{nmol}$ of each deoxynucleotide, $50 \mathrm{mmol} / 1 \mathrm{KCl}, 10$ $\mathrm{mmol} / 1 \mathrm{Tris} \mathrm{HCl}, \mathrm{pH} 8,1.5 \mathrm{mmol} / 1 \mathrm{MgCl}_{2}$, and $0.1 \%$ gelatin in a final volume of 501 . Taq polymerase was added after the first step of denaturation $\left(10\right.$ minutes, $95^{\circ} \mathrm{C}$ ) followed by 30 cycles of denaturation $\left(94^{\circ} \mathrm{C}, 40\right.$ seconds), annealing $\left(55^{\circ} \mathrm{C}, 30\right.$ seconds), and elongation $\left(72^{\circ} \mathrm{C}, 40\right.$ seconds), with a final elongation step $\left(72^{\circ} \mathrm{C}, 10\right.$ minutes). An aliquot of amplified DNA was mixed with the loading buffer. Samples were denaturated for 10 minutes at $94^{\circ} \mathrm{C}$ and loaded on a $6 \%$ polyacrylamide denaturing gel. After blotting, membranes were fixed in $0.4 \mathrm{~mol} / 1$ sodium hydroxide and hybridised for two hours with $(\mathrm{CA})_{12}\left({ }^{32} \mathrm{P}\right)$ labelled probes. Blots were washed once in $2 \times \mathrm{SSC}$, $0.1 \%$ SDS for 10 minutes at room temperature and autoradiographed. DNA of CEPH subject 1347-02 was included in each experiment as control of allele size. Allele frequencies were based on the genotypes of parents of a subset of the CEPH panel. To calculate pairwise lod scores, we used the M-LINK program of the LINKAGE package (version 5.1). $\mathrm{HCH}$ was tested assuming that the disease is transmitted as an autosomal dominant trait (gene frequency $f=1 / 30000$ ) with full penetrance. For mutation studies, a combination of single 

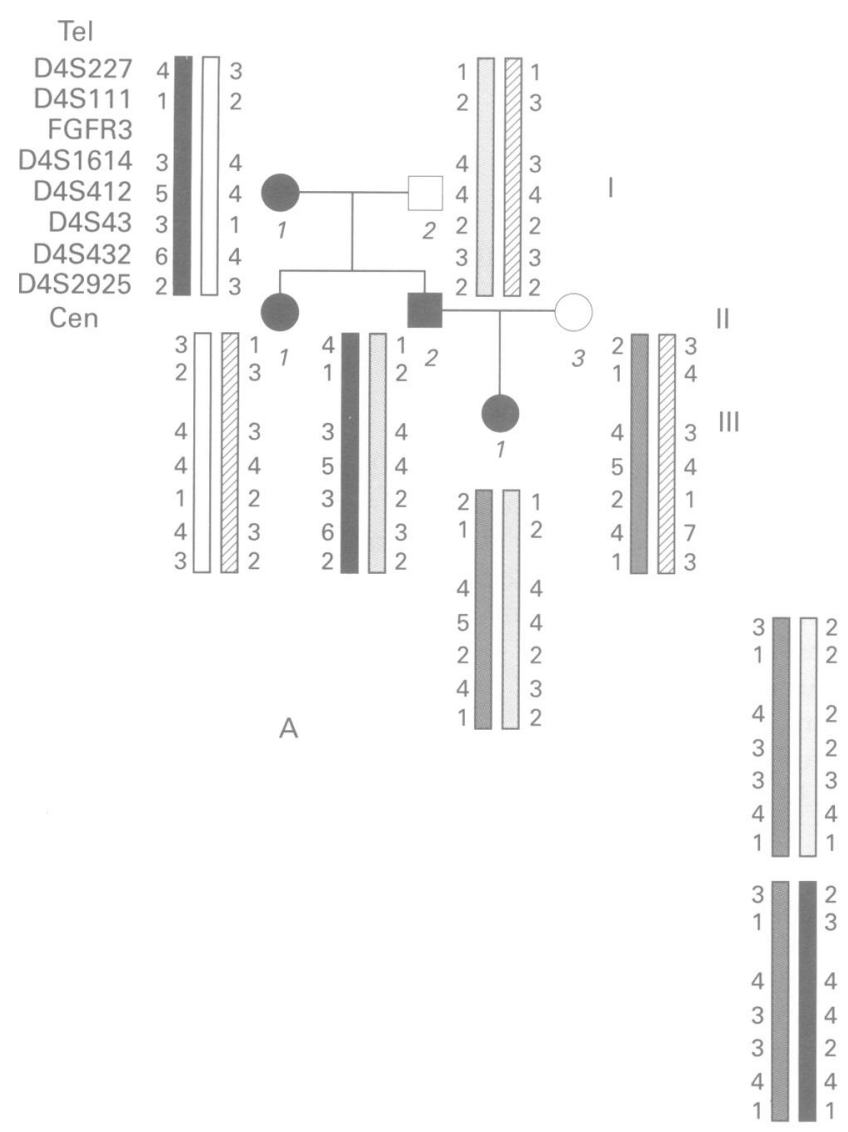
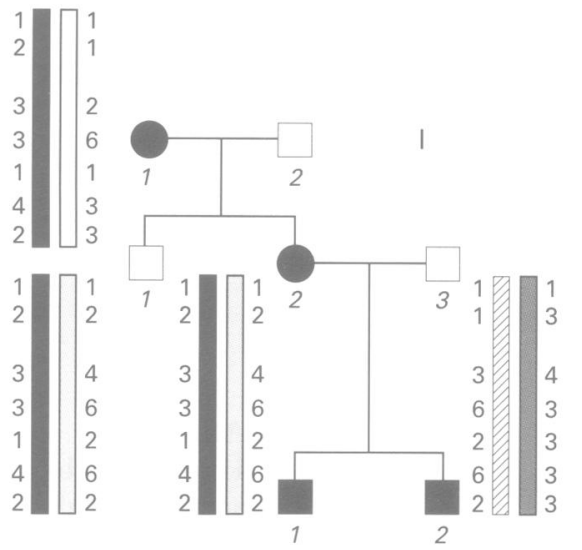

Figure 1 Evidence of genetic heterogeneity in hypochondroplasia. Three HCH pedigrees excluding linkage to chromosome 4p16.3 are shown.

Table 1 Phenotype-genotype correlation in $\mathrm{HCH}$

\begin{tabular}{|c|c|c|c|c|c|c|c|}
\hline & & $\begin{array}{l}\text { Short } \\
\text { interpedicular } \\
\text { distance }\end{array}$ & Macrocrania & $\begin{array}{l}\text { Short } \\
\text { phalanges }\end{array}$ & $\begin{array}{l}\text { Short } \\
\text { femoral neck }\end{array}$ & $\begin{array}{l}\text { Shortened } \\
\text { long bones }\end{array}$ & $\begin{array}{l}\text { Elongated } \\
\text { fibulae }\end{array}$ \\
\hline Familial $\mathrm{HCH}$ & 16 & & & & & & \\
\hline N540K mutation & 8 & + & ++ & ++ & ++ & ++ & ++ \\
\hline Unlinked to $4 \mathrm{p} 16.3$ & 6 & + & + & $+1-$ & $+1-$ & $+1-$ & - \\
\hline Uninformative to $4 \mathrm{p} 16.3$ & 2 & + & + & ++ & -++ & ++ & ++ \\
\hline Sporadic $\mathrm{HCH}$ & 13 & & & & & & \\
\hline N540K mutation & 13 & + & ++ & ++ & ++ & ++ & ++ \\
\hline Total & 29 & & & & & & \\
\hline
\end{tabular}

strand conformation polymorphism (SSCP) analysis and direct sequencing of amplification products was used (automatic DNA sequencer ABI $370 \mathrm{~A}$ ).

\section{Results}

We first tested $\mathrm{HCH}$ for allelism to $\mathrm{ACH}$ at the FGFR3 locus, as $\mathrm{ACH}$ has been previously ascribed to mutations in the FGFR3 gene at locus D4S98 on chromosome 4 p16.3. The order tel-(D4S227, PDE $\beta)-0.01-$ (D4S111, IDUA) - $0.02-(\mathrm{D} 4 \mathrm{~S} 98$, FGFR3) - 0.01 - D4S1614 - 0.001 - D4S412 - 0 - D4S43 - 0.020 - D4S432 - 0.01 - D4S2925 - cen has been established by analysis of $\mathrm{CEPH}$ reference data (genetic distances in parentheses). Among our 16 familial $\mathrm{HCH}$ cases, 11/16 were informative for linkage analysis and $5 / 16$ were available for mutation analysis only. Surprisingly, when the 11 informative $\mathrm{HCH}$ families were tested, nonsignificant results were obtained for linkage of the disease gene to several polymorphic loci of chromosome $4 \mathrm{p} \quad(\mathrm{Zmax}=0.8$ for locus
D4S111 at $\mathrm{q}=0.1$ ). Haplotype analyses provided direct evidence of exclusion of chromosome 4p16.3-pter in three $\mathrm{HCH}$ pedigrees (fig 1) while the other eight families were consistent with linkage to the $\mathrm{ACH}$ locus $(\mathrm{Zmax}=2.5$ at locus $\mathrm{D} 4 \mathrm{~S} 227$ at $\mathrm{q}=0)$.

Our strategy, therefore, was to look for the N540K FGFR3 mutation ${ }^{12}$ in our $\mathrm{HCH}$ families which showed no recombination with chromosome 4p16.3 markers (eight families), in uninformative $\mathrm{HCH}$ families (five families), and in sporadic cases (13 cases). Two abnormal patterns of migration indicative of sequence variations in the TK1 domain were observed in $8 / 16$ familial forms and $13 / 13$ sporadic cases of $\mathrm{HCH}$ (fig 2). Sequence analyses showed heterozygosity for the $\mathrm{C} \rightarrow \mathrm{A}$ or the $\mathrm{C} \rightarrow \mathrm{G}$ transitions at nt 1620 , changing asparagine 540 into lysine $(\mathrm{N} 540 \mathrm{~K})$ in all sporadic cases and in $8 / 16$ familial cases, but not in the three families unlinked to chromosome $4 p$ (fig 3, table 1).

Considering the genetic heterogeneity of $\mathrm{HCH}$, the clinical and radiological profiles of the patients were reviewed a posteriori. Based 
on the results of our genetic analysis, $\mathrm{HCH}$ patients were split into two groups. In the group of $\mathrm{HCH}$ patients harbouring the $\mathrm{N} 540 \mathrm{~K}$ mutation (group 1, 23 patients), we observed relative macrocrania $(+1 \mathrm{SD})$ with a high and large forehead and short hands (fig 4). Radiographs disclosed broad and short long bones with metaphyseal flaring and overmodelling and an increased length of the fibulae. Femoral heads were slightly enlarged with short femoral necks. Metacarpals and phalanges were short and stubby (fig 5). In two uninformative families, no FGFR-3 mutation was identified but affected subjects had very

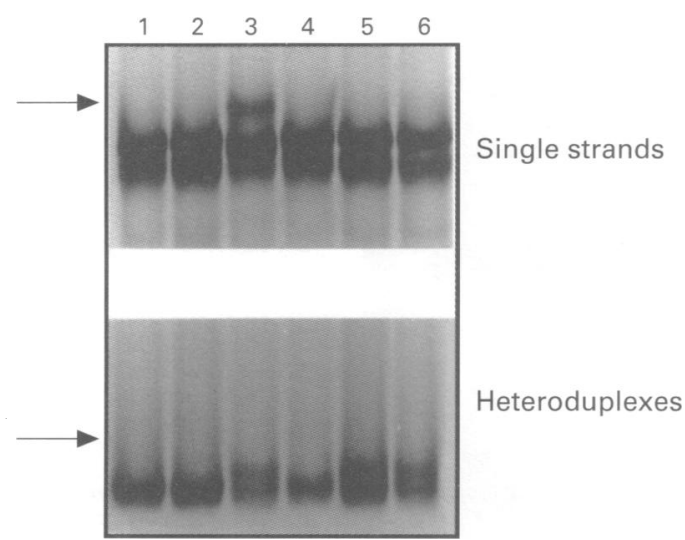

Figure 2 Single strand conformation polymorphism analysis of the tyrosine kinase domain of FGFR3 gene in three HCH patients (lanes 3, 5, and 6) and controls (lanes 1,2 , and 4). Arrows indicate abnormal bands in the probands.
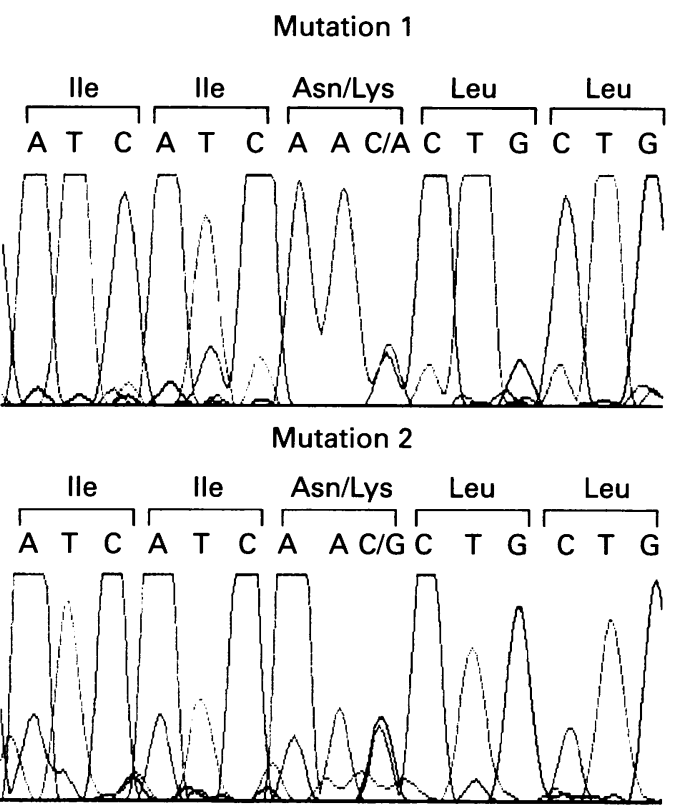

Normal sequence
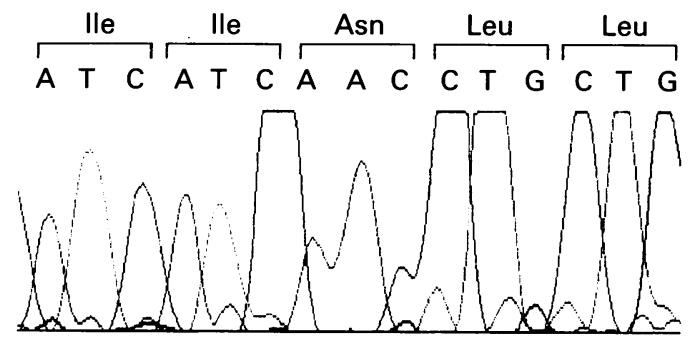

Figure 3 Sequence analysis of the tyrosine kinase domain of the FGFR3 gene in $\mathrm{HCH}$. short stature (-3, $-4 \mathrm{SD})$, relative macrocephaly, and $x$ ray findings similar to those observed in patients carrying the N540K mutation. Finally, in the three pedigrees inconsistent with linkage to chromosome 4p16.3 (group 2, six patients), relative macrocephaly was also present (fig 4), but shortening of the long bones and iliac wings was milder, the hands were normal, and no metaphyseal flaring, overmodelling, or elongated fibulae were noted (fig 5).

\section{Discussion}

Hypochondroplasia is a difficult condition to diagnose, especially in the newborn period. Indeed, the short stature is usually only recognised after 2 years and relative macrocephaly is present in only $57 \%$ of cases. ${ }^{24}$ Narrowing of interpedicular distances with short pedicles and shortened tubular bones are minimal inclusion criteria. ${ }^{34}$

The present study supports the view that $\mathrm{HCH}$ is a clinically and genetically heterogeneous condition. Indeed, while the majority of $\mathrm{HCH}$ cases were allelic to $\mathrm{ACH}$ and ascribed to the previously described $\mathrm{N} 540 \mathrm{~K}$ mutation in the FGFR3 gene, ${ }^{12}{ }^{13}$ several pedigrees clearly excluded linkage of the disease gene to chromosome $4 p$ in our series, as in other reports. ${ }^{1415}$ Haplotype analyses in the three unlinked families provided evidence of exclusion of chromosome $4 \mathrm{p}$ in pedigree $\mathrm{A}$. Although variable expressivity is a possibility in pedigrees $B$ and $C$, clinical examination of the two recombinant subjects failed to disclose any clinical features of hypochondroplasia, such as short stature (subjects B II.1, $168 \mathrm{~cm}$, and C II. $2,165 \mathrm{~cm}$ ), micromelia, or macrocephaly.

Interestingly, when patients were divided into two groups based on the detection of FGFR3 mutations (group 1) or exclusion of the 4 p16.3 region in our series (group 2), it appeared that the $\mathrm{N} 540 \mathrm{~K}$ mutation was associated with a severe phenotype resembling $\mathrm{ACH}$
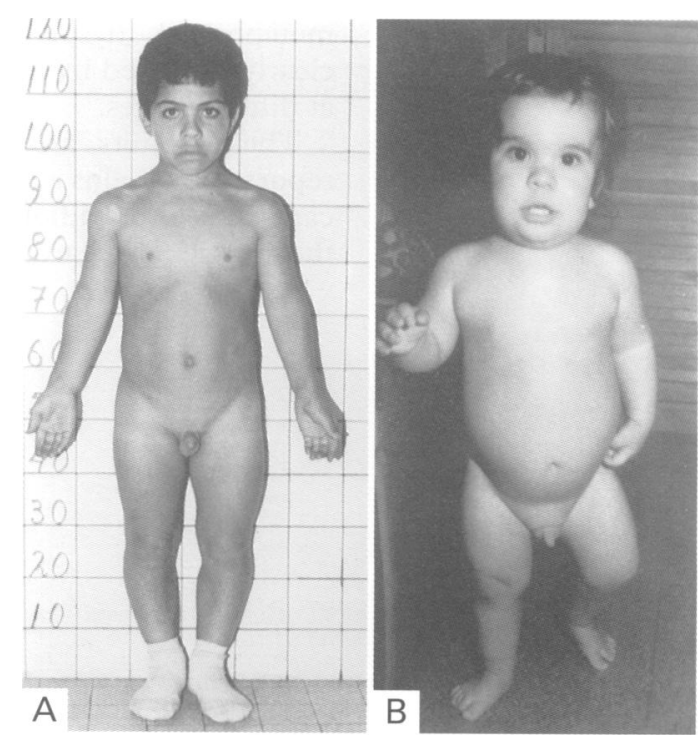

Figure 4 Variable clinical phenotypes in $\mathrm{HCH}$. (A)

Sporadic case harbouring the N54OK FGFR3 mutation at the age of 12 years; $(B)$ familial case unlinked to chromosome 4p16 (pedigree B, III.2 at the age of 4 years). Note micromelia and relative macrocephaly with high forehead. 

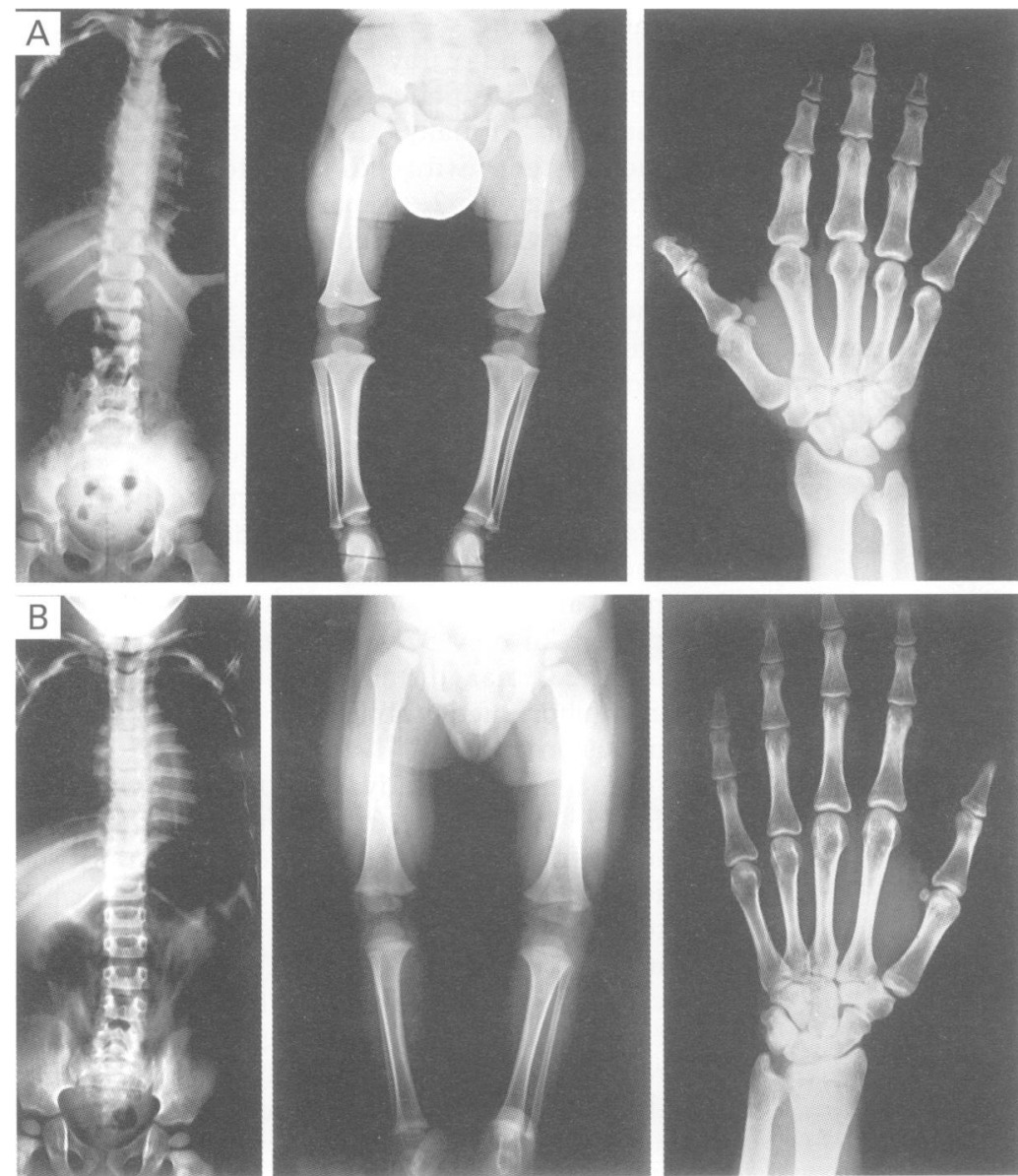

Figure $5 X$ rays of the spinal column, hands, long bones, and femoral necks in a case of $H C H$ harbouring the N540K mutation (type 1, panel $A$ ) or unlinked to chromosome 4 p16.3 (type 2, panel B).

(overmodelling of the long bones, metaphyseal flaring, increased length of the fibulae, small iliac wings, short femoral necks and tibiae, broad and short metacarpals and phalanges). By contrast, in $\mathrm{HCH}$ unlinked to chromosome $4 \mathrm{p} 16.3, x$ ray anomalies were milder, the hands and long bones were normal, and no metaphyseal flaring was noted. In this latter group, other diagnoses such as dyschondrosteosis or metaphyseal dysplasia type Schmid were clearly excluded by radiographic examinations at different ages.

These results are at variance with those reported by Bellus et al, ${ }^{12}$ who found no significant clinical or radiological differences among their patients regardless of the mutant geno- type. $\mathrm{HCH}$ should be regarded therefore as a clinically and genetically heterogeneous condition, with one clinical subtype being allelic to ACH. This heterogeneity contrasts with the clinical and genetic homogeneity of $\mathrm{ACH}$, whose invariable clinical severity is accounted for by a single mutation in the transmembrane domain of the FGFR3 gene in $98 \%$ of patients (G380R). The clinical variability of $\mathrm{HCH}$ has been previously noted by Maroteaux and Falzon, ${ }^{2}$ Wynne Davies et $a l^{3}$ and Hall and Spranger. ${ }^{4}$ Hitherto, however, the genetic basis of clinical variability in $\mathrm{HCH}$ has remained unknown. The demonstration of genetic heterogeneity in $\mathrm{HCH}$ provides a rationale for the clinical variability of this condition and should help in directing molecular studies both in sporadic cases and in uninformative $\mathrm{HCH}$ families.

1 Ravenna F. Achondroplasie et chondrohypoplasie, contribution clinique. Nouv Iconog Salpet 1913;26:157-84.

2 Maroteaux P, Falzon P. Hypochondroplasie: revue de 80 cas. Arch Fr Pediatr 1988;45:105-9.

3 Wynne Davies R, Walsh WK, Gormley J. Achondroplasia and hypochondroplasia: clinical variation and spinal stenosis. F Bone foint Surg (Br) 1981;63:508-15.

4 Hall BD, Spranger J. Hypochondroplasia: clinical and radiological aspects in 39 cases. Radiology 1979;133:95100.

5 McKusick VA, Kelly TE, Dorst JP. Observations suggesting allelism of the achondroplasia and hypochondroplasia genes. F Med Genet 1973;10:11-16.

6 Velinov M, Slaugenhaupt SA, Stoilov I, Scott CI, Gusella JF, Tsipouras $P$. The gene for achondroplasia maps to the telomeric region of chromosome 4p. Nature Genet telomeric region

7 Le Merrer M, Rousseau F, Legeai-Mallet L, et al. A gene for achondroplasia-hypochondroplasia maps to chromosome 4p. Nature Genet 1994;6:318-21.

8 Rousseau F, Bonaventure J, Legeai-Mallet L, et al. Mutations in the gene encoding fibroblast growth factor receptor-3 in achondroplasia. Nature 1994;371:252-4.

9 Shiang R, Thompson LM, Zhu YZ, et al. Mutations in the transmembrane domain of FGFR3 cause the most common genetic form of dwarfism, achondroplasia. Cell 1994;78:335-42.

10 Bellus GA, Hefferon TW, Ortiz de Luna RI, et al. Achondroplasia is defined by recurrent $\mathrm{G} 380 \mathrm{R}$ mutations Achondroplasia is defined by recurrent G380R

11 Hecht JT, Herrera CA, Greenhaw GA, Francomano CA Bellus GA, Blanton SH. Confirmatory linkage of hypochondroplasia to chromosome arm 4p. Am $\mathcal{F}$ Med Gene 1995;57:505-6.

12 Bellus GA, McIntosh I, Smith EA, et al. A recurrent mutation in the tyrosine kinase domain of fibroblast growth factor receptor 3 causes hypochondroplasia. Nature Gene 1995;10:357-9.

13 Prinos P, Costa T, Sommer A, Kilpatrick MW Tsipouras P. A common FGFR3 gene mutation in hypochondroplasia. Hum Mol Genet 1995;4:2097-101.

14 Rousseau F, Bonaventure J, Hayden MR, et al. Not all hypochondroplasia families are linked to chromosome $4 \mathrm{p} 16.3$. chondroplasia families are linked to chromo

15 Stoilov I, Kilpatrick MW, Tsipouras P, Costa T. Possible genetic heterogeneity in hypochondroplasia. 7 Med Gene 1995;32:492-3. 